\title{
Kadın iş gücünün yer aldığı ağaçlandırma işlerinin iş sağlığı ve güvenliği açısından değerlendirilmesi
}

\author{
Mehmet Eker a,* (D), Fatma Gamze Korkmaz ${ }^{\text {b }}$ (D)
}

\begin{abstract}
Özet: Bu çalışmada, orman ağaçlandırma faaliyetlerinde çalışan kadın işçilerin rolü, çalışmaktan kaynaklı sağlık problemlerinin araștırılması ve çalıșma koşullarının iş sağlığı ve güvenliği açısından değerlendirilmesi amaçlanmıştır. Mersin Orman Bölge Müdürlügü, Silifke Orman İ̧̧letme Müdürlüğü bünyesindeki ağaçlandırma çalışmalarında; fidan dikim işleri ölçeğinde basit bir iş analizi yapılarak iş adımları ortaya konulmuş, işçiler gözlemlenmiş ve de 91 kadın işçi ile çalışma şartlarını, yapılan işi ve çalı̧̧anları değerlendirmeye yönelik 136 sorudan oluşan anket uygulaması gerçekleştirilerek veri-bilgi toplanmıştır. Arazi gözlemleri ve risk kontrol listeleri yardımıyla hareket ve risk analizleri yapılarak iş sağlığı ve güvenliği açısından değerlendirmeler yapılmıştır. Ağaçlandırma işlerinde; kadın iş gücü katılımının fidan dikimi aşamasında odaklandığı; bölgesel ve yöresel ölçekte çalışanların \% 70' e yakınının kadın çalışanlardan oluştuğu belirlenmiştir. Kadın çalışanların \%60' tan fazlasının kas iskelet sistemi rahatsızlıklarından; yaklaşık \% 42'sinin ise sürekliliği olan çeşitli sağlık problemlerinden yakındıkları belirlenmiştir. Vücut kitle indeksi değerlerine göre \% 50.55'inin fazla kilolu olduğu ortaya çıkmıştır. Fidan dikim işinin gerektirdiği çalışma postürünün ergonomik düzenleme gerektirecek şekilde yüklenme ve zorlanmalara neden olması, çalışanların nitelikleri, kısa süreli ancak sürekli tekrarlı hareketleri işçilerin yakınmalarını desteklemektedir. Katılımcılardan yaklaşık \% 8'inin yılda en az bir defa kazaya uğradığı bildirilmiştir. Kişisel koruyucu donanımlardan sadece eldivenlerin kullanıldığı ancak bu işe uygun olmadığı belirlenmiştir. Çalışanların yaklaşık \%95'inin iş sağlığı ve güvenliği mevzuatından haberdar olmadıkları ortaya çıkmıştır. Fiziksel, ergonomik ve psikolojik risk faktörlerinin ağırlıkta olmasına rağmen, fidan dikim işlerinin az tehlikeli ve hafif-ağır işler kategorisinde yer alabileceği belirlenmiştir.
\end{abstract}

Anahtar Kelimeler: Kadın iş gücü, Kadın orman iş̧̧ileri, Ağaçlandırma işleri, İş sağlığı ve güvenliği, Risk değerlendirmesi

\section{Assessment of women workforce on afforestation activities in terms of occupational health and safety}

\begin{abstract}
In this study, it was aimed to investigate the existence of female workers working in forest afforestation activities and their role in these works, to investigate the health problems, and to evaluate the working conditions in terms of occupational health and safety. By making a simple job analysis, the work steps revealed, the workers were observed, and data-information was collected together with field observations by conducting face-to-face surveys and interviews with 91 female workers, consisting of 136 questions. With the help of field observations and risk checklists, movement and risk analyzes were made and evaluated. It has been determined that nearly $70 \%$ of regional employees are female employees. More than $60 \%$ of female employees suffer from musculoskeletal disorders. It has been determined that approximately $42 \%$ of them complain of various health problems that are continuous. According to the body mass index values, $50.55 \%$ were found to be overweight. The work posture required by the sapling planting job causes loads and strains that require ergonomic regulation, the qualifications of the employees, and the short-term but constantly repetitive movements support the complaints of the workers. It has been reported that approximately $8 \%$ of the participants have an accident at least once a year. It has been determined that only revealed that approximately $95 \%$ of the employees are not aware of the occupational health and safety legislation. Although physical, ergonomic and psychological risk factors are predominant, it is determined that sapling planting works can be included in the category of less dangerous and light-heavy work.
\end{abstract}

Keywords: Female workforce, Female forest workers, Afforestation works, Occupational health and safety, Risk evaluation

\section{Giriș}

İklim değişiminin etkilerinin somut şekilde hissedildiği günümüzde, ormansızlaşmayla mücadele ve orman kaynaklarının sürekliliği için ağaçlandırma faaliyetleri gerçekleştirilmektedir. Ülkemizde artan nüfusla beraber odun hammaddesi ihtiyacı da artmakta ve bu ihtiyacın karşılanması ve kolektif faydaların sağlanabilmesi için ağaçlandırma faaliyetlerine devam edilmektedir (OGM, 2021a). 2020 yılı yatırım programında; 155382 ha alanda etüt- proje, 19312 ha endüstriyel ağaçlandırma olmak üzere toplam 28632 hektar ağaçlandırma tesis çalışması gerçekleştirildiği (OGM, 2021b) bildirilmektedir. Buna göre, ağaçlandırma faaliyetlerinin süreklilik göstereceği belirgindir. $\triangle$ a Isparta Uygulamalı Bilimler Üniversitesi, Orman Fakültesi, Isparta

b Isparta Uygulamalı Bilimler Üniversitesi, Lisansüstü Eğitim Enstitüsü, Isparta

@ * Corresponding author (İletişim yazarı): mehmeteker@isparta.edu.tr

$\checkmark \quad$ Received (Geliş tarihi): 18.08.2021, Accepted (Kabul tarihi): 15.09.2021
Citation (Atıf): Eker, M., Korkmaz, F.G., 2021. Kadın iş gücünün yer aldığı ağaçlandırma işlerinin iş sağlığ değerlendirilmesi. Turkish Journal of Forestry, 22(3): 283-294. DOI: $\underline{10.18182 / \text { tjf.963681 }}$ 
Ağaçlandırma işleri, ormancılık iş kolunun geniş yelpazesi içinde kalmakta ve çoğunlukla tehlikeli, kirli ve zor koşullarda gerçekleştirilen işlerden sayılmaktadır (Poschen, 1993). Mesleki Yeterlilik Kurumu (MYK, 2021), ağaçlandırma işlerini ve bu işlerde çalışacakları "Orman Ağaçlandırma ve Fidan Yetiştirme İşçisi” adıyla tanımlamış; ağaçlandırma işçilerinin yeterlilik ve görevlerini tarif etmiş ve de iş sırasında iş sağlığ 1 ve güvenliği (ISG) önlemlerini gerektirecek kaza ve yaralanma riskleri bulunduğunu işaret etmiştir.

Ormancılık iş kolunda; orman kaynaklarının korunması yanında, ormandan faydalanan ve ormana fayda sunan insan kaynaklarının da korunması esası; ağaçlandırma işlerinde İSG konusunu ön plana çıkarmaktadır. Çalışanların ruhsal, bedensel ve sosyal yönden iyilik hallerinin sağlanması, sürdürülmesi ve iyileştirilmesini ve çalışanların karşı karşıya kaldıkları tehlikelerin ortadan kaldırılması veya azaltılması için alınan önlemler bütünlüğünü kapsayan İSG (Acar ve Üçüncü, 2020); 2012 yılında yürürlüğe giren 6331 sayılı İş Sağlı̆̆ı ve Güvenliği Kanunu ile garanti altına alınmıştır. Uygulama süreci halihazırda yapılandırılmaya devam eden İSG mevzuatı, İş Kanunu (4857 sayılı) ve Sosyal Sigortalar ve Genel Sağlık Sigortası Kanunu (5510 sayılı) paralelinde yürütülmektedir. Ormancılık uygulamalarının büyük çoğunluğu, orman köylüleri tarafindan kendi nam ve hesaplarına çalışılarak (Gökbayrak, 2005) periyodik ve kısa süreli işler şeklinde gerçekleştirildiğinden yasal mevzuatın bu işlere etkisi sınırlı kalmaktadır. Ağaçlandırma işlerinin de; yasal mevzuat çerçevesinde öncelikle işyerine yakın, çoğunluğu kadın çalışanlardan oluşan, orman köylüleri tarafından yürütüldüğü bilinmektedir.

Birleşmiş Milletler Nüfus Fonu (UNFPA) verilerine göre; dünya nüfusu yaklaşı 7.7 milyar insandan oluşmaktadır (UNFPA, 2019). Türkiye İstatistik Kurumu (TÜIKK) 2020 yılı verilerine göre ülkemizde 83614362 kişi yaşamaktadır. $\mathrm{Bu}$ sayının 41.91 milyonunu (\%50.1'ini) erkekler, 41.69 milyonunu (\%49.9' unu) da kadınlar oluşturmaktadır (TÜİK, 2021). Uluslararası Çalışma Örgütü (ILO)' nun 2018 yılı raporuna göre kadınların iş gücüne katılım oranı erkeklerden \%26.5 daha azdır (ILO, 2018). Toplumsal cinsiyet eşitsizliği (Korkmaz ve Alkan, 2015; Korkmaz ve Baykal, 2018) bu durumun başlica nedeni olarak gösterilmektedir. TÜİK, 2019 yılı verilerine göre işgücüne katılım oranının kadınlar için \%34,5; erkekler için \%71,8 olduğu belirtilmiştir (ILO, 2021). Kadınların eğitim seviyesi düştükçe, iş gücüne katılım oranının da düştüğü bilinmektedir. TÜİK' in 2019 verilerine göre okuryazar olmayan kadınların iş gücüne katılım oranının \%15.9 iken yükseköğretim mezunu kadınların katılım oranının ise \%72.7 olduğu belirtilmiştir (TÜİK, 2020a ve 2020b). Kadın çalışanlar, Aktif İşgücü Hizmetleri Yönetmeliği'ne göre özel politika veya uygulama gerektiren ve istihdamında daha fazla güçlük çekilen dezavantajlı grubu oluşturmaktadır. Bununla birlikte, ormancılık işlerinde kadın istihdamı (Forworknet, 1999) ve bu işlerdeki rolü konusunda tatmin edici düzeyde bilgiye rastlamak zordur (Acar ve Eker, 2001a). Beden gücü ile yapılan işlere bireysel veya aileleriyle birlikte katılım sağlayan kadınların yaptıkları iş tipi, iş yükü, iş kazaları ve meslek hastalıkları hakkında kayıt, veri ve bilgi eksikliğinin olduğu, belirgindir (Eker ve Çoban, 2019).

İSG açısından bir işin, çalışanın ve/veya iş ortamının değerlendirilmesi; hem bilimsel hem de yasal mevzuat açısından tehlike ve risk faktörlerinin değerlendirilmesi ölçeğinde gerçekleştirilebilmektedir (Acar ve Üçüncü, 2020). Bir işin insan onuruna yaraşır ve yapılabilir olması; o işin çalışılabilir olması, tehlike ve risklerden arındırılmış veya etkilerinin azaltılmış olması ve işin bedensel ve de zihinsel yönden sürdürülebilir olması gerekliliği anlamına gelir (ILO, 2021). Bu yönde bir analizin/değerlendirmenin yapılması için birçok risk değerlendirme yöntemi geliştirilmiş ve uygulanagelmektedir (Ünver-Okan vd., 2017; Ünver-Okan vd., 2019; Acar ve Üçüncü, 2020; Eker ve Kılıç, 2021). Bununla birlikte çalışana, işe ve çalışma ortamına ilişkin çeşitli risk faktörlerinin değerlendirilebilmesi için iş ve hareket analizleri yapılmakta; işlerin risk seviyeleri belirlenerek alınması gereken önlemler tayin edilebilmektedir. Ormancilik sektöründe orman ürünleri hasadı ve transportunda, orman depolarında, fidanlıklarda vb. yerlerde çalışan ișçilere yönelik İSG değerlendirmelerine rastlanırken (Elbir, 2019; Küçükarslan, 2017; Bozkurt, 2017) ağaçlandırma işlerinde çalışanlar ve özellikle kadın işçilerin ISG açısından konu edildiği bir araştırmaya rastlanmamıştır.

$\mathrm{Bu}$ çalışmanın amacı; ağaçlandırma işlerinde çalışan kadın iş gücünün rolünü ortaya koymak, bu işlerde çalışan kadınların hangi iş aşamalarında ve ne yoğunlukta görev üstlendiklerini tespit etmek, ağaçlandırma ve özellikle fidan dikim işlerini (iş yeri, kullanılan ekipmanlar, yapılan iş miktarı, iş tekniği ve kadın iş gücü açısından) iş-çalışan ergonomisi açısından değerlendirmek, fidan dikimi işlerini İSG açısından değerlendirmek, kadın çalışanlar açısından bu işlerin avantaj ve dezavantajlarını belirlemek ve karşılaştıkları zorlukları ve problemleri sıralamaktır.

\section{Materyal ve yöntem}

Araştırmada kullanılan veri ve bilginin elde edilebilmesi için Mersin Orman Bölge Müdürlüğü Silifke Orman İşletme Müdürlüğü’ne bağlı Mara Orman İşletme Şefliği (MOİş) bünyesindeki Kıca Köyü, Kır Obası, Haçpınarı Mevkii (3701'35” K - 3347’24” D) ağaçlandırma sahası, çalışma alanı olarak belirlenmiştir. Ağaçlandırılan sahanın rakımı ortalama $1450 \mathrm{~m}$ olup, 0-40 eğim grubunda yer alan güney bakılı bu arazinin ortalama eğimi \%25' dir. Bu sahada bölgeye uyumlu fidan türü olarak tüplü $(2+0$ yaşında) Toros Sediri (Cedrus libani A. Rich.) fidanı kullanılmıştır. Fidan dikimi; toprak işlemede paletli ekskavatörlerin kullanıldığ 1 MEROR (Mersin Yöresinde Karstik Arazilerde Ekskavatörle Toprak İşleme) tipi teraslarda gerçekleştirilmiştir. Ağaçlandırma işleri, mevzuat çerçevesinde 18 No'lu Ağaçlandırma Tamimi'ne göre yapılmaktadır. Ağaçlandırma süreci genel olarak; etüt ve projelendirme, arazi hazırlığı, fidan dikimi ve bakım çalışmalarından oluşur. Ağaçlandırma faaliyetlerinin özünü fidan dikimi işleri (Çizelge 1) oluşturmaktadır.

Araştırma sahasında; Mersin İli Silifke İlçesi'ne bağlı Meydan ve Kıca Köyü'ne kayıtlı kadın orman köylüleri (kooperatife bağlı mükellefler) ile çalışılmıştır. Buradaki, ağaçlandırma işine katılan tüm kadınlar, araştırmaya katılmaya da gönüllü olmuşlardır. Fidan dikim süreciyle ilgili iş tekniğinin etüdünde bu çalışanların doğrudan doğruya gözlemlenmesinden elde edilen verilerden yararlanılmış, önceden hazırlanmış değerlendirme formları doldurulmuş ve yüz yüze anketler de yine bu çalışanlarla yapılmıştır. Çalışmaya katılan kadın işçilerin fiziksel 
niteliklerine ilişkin tanımlayıcı istatistikler Çizelge 2'de özetlenmiştir.

Fidan dikiminde kullanılan belli başlı el aletleri; dikim çapası ve bă̆ bıçağıdır (halk arasında bıçkı olarak adlandırılmaktadır). Dikim çapası; 40-60 cm arasında değişen uzunluğa sahip ahşap bir sap ve yaklaşık 0.9-1.25 kg ağırlığında $20-25 \mathrm{~cm}$ uzunluğundaki metal bir kazıcı aksamdan oluşmuş toplam ağırlığ $1.4-1.8 \mathrm{~kg}$ civarında işlevsel el aletidir. Çapa yardımıyla hem etrafta kalan diri örtünün temizliği yapılır hem de dikim işlemi uygulanır. Bağ bıçağı ise ahşap bir sap ve metal kesici kısımdan oluşan yaklaşık 20-30 cm uzunluğunda hafif (250 g'dan az) ve testere dişli ağız açıklığı olan kavisli bir tür bıçaktır. Bağ bıçağı önce dip kesimi-düzeltmesi yapılmasında ve polietilen torbanın kesilip fidan çıkarılmasında kullanılır.

Araştırmada kullanılan veri-bilgi toplama ve kayıt karneleri/formları aşağıda kısaca tanıtılmıştır.

Ağaçlandırma işçileri bilgi formu: Akdeniz Bölgesi'nde ağaçlandırma işkoluna katılım sağlayan kadın iş gücü oranını belirlemek amacıyla kullanılan ve kişisel iletişim yoluyla doldurulan kayıt evrakıdır.

İş akışı gözlem formu: Özellikle fidan dikim işlerinin hangi sırayla hangi iş adımlarından oluştuğunu belirleyebilmek için iş akışının tarif edilmesine yarayacak bir şemanın oluşturulması amacıyla numaralandırılma esasına dayalı basit bir formdur. Adeta iş örneklemesi yönteminde (Yıldırım, 1989) olduğu gibi işçilerin belirli aralıklarla izlenip hangi işi yaptıklarının yazıldığ $1 /$ işaretlendiği formdur.

Çizelge 1. Fidan dikim aşaması

\begin{tabular}{|c|c|c|}
\hline İş akış1 & İș Ögesi & İşin Tanımı \\
\hline \multirow{7}{*}{ Dikim } & $\begin{array}{l}\text { Çukur } \\
\text { açma }\end{array}$ & $\begin{array}{l}\text { Önceden işçiler tarafından hazırlanan } \\
\text { dikim yastıklarında } 2 \mathrm{mx} 6 \mathrm{~m} \text { aralık } \\
\text { mesafe ile dikim çukurları açılması } \\
\text { faaliyetidir. }\end{array}$ \\
\hline & Dip kesimi & $\begin{array}{l}\text { Tüpün içinde kıvrılmış vaziyette olan } \\
\text { köklerin fidan gelişimini engellememesi } \\
\text { için tüplü fidanların dip tarafindan } 1 \mathrm{~cm} \\
\text { eninde kesilip atılması faaliyetidir. }\end{array}$ \\
\hline & $\begin{array}{l}\text { Fidan } \\
\text { yerleştirme }\end{array}$ & $\begin{array}{l}\text { Dikim kazması ile açılan fidan dikim } \\
\text { çukuruna fidanların konulması } \\
\text { faaliyetidir. }\end{array}$ \\
\hline & $\begin{array}{l}\text { Toprak } \\
\text { atım1 }\end{array}$ & $\begin{array}{l}\text { Fidanın kök boğazına kadar toprak ile } \\
\text { doldurulması faaliyetidir. }\end{array}$ \\
\hline & Sıkıştırma & $\begin{array}{l}\text { Kökün hava almaması için ayakla } \\
\text { toprağın sıkıştırılması faaliyetidir. }\end{array}$ \\
\hline & $\begin{array}{l}\text { Teras } \\
\text { formu } \\
\text { verilmesi }\end{array}$ & $\begin{array}{l}\text { Dikim esnasında bozulan terasa tekrar } \\
\text { teras formu verme faaliyetidir. Böylece } \\
\text { toprağın çatlaması ve kaynaklanması } \\
\text { azaltılacak, yağışların terasları yırtması } \\
\text { engellenecek ve terasların daha çok su } \\
\text { tutması sağlanacaktır. }\end{array}$ \\
\hline & $\begin{array}{l}\text { Taşla } \\
\text { sabitleme }\end{array}$ & $\begin{array}{l}\text { Don atmasını engellemek için fidan } \\
\text { etrafina birkaç adet taşın konulması } \\
\text { faaliyetidir. }\end{array}$ \\
\hline
\end{tabular}

Çizelge 2. Kadın çalışanlara $(N=91)$ ait bazı fiziksel özellikler

\begin{tabular}{lcccc}
\hline Temel istatistikler & Yaş & Boy & Kilo & VKI* \\
\hline Ortalama & 44.60 & 155.45 & 66.73 & 27.54 \\
En küçük & 20.00 & 149.00 & 50.00 & 21.50 \\
En büyük & 70.00 & 165.00 & 120.00 & 46.80 \\
Standart sapma & 11.54 & 4.32 & 10.50 & 4.00 \\
\hline *Vü
\end{tabular}

$\frac{\text { Standart sapma }}{\text { *Vücut kütle indeksi }}$
Anket formu: Daha önceki çalışmalarda (Acar ve Eker, 2001b) geliştirilip ormancılıkta üretim, depo ve fidanlık işçilerine uygulanan (Eker vd., 2008) anketlerden yararlanılarak ağaçlandırma işleri ve işçilerine yönelik şekilde düzenlenmiş formlardır. Çalışanların genel kişisel bilgileri (yaş, boy-kilo, medeni hal, eğitim, kazanç vb.), kullandıkları alet ve ekipmanlar, yapılan işin kontrolü, iş esnasında ve sonrasında maruz kalınan sağlık problemleri ve sorunlar ile İSG sebebiyle alınan önlemlerin ortaya konulması amaciyla hazırlanan bu anket formu 136 sorudan oluşturulmuştur.

Çalışma alanı gözlem formu: Çalışanların bireysel olarak gözlenmesi ve risk değerlendirmesine yarayacak verinin toplanması amacıyla Engür (2019) tarafından odun üretim işlerinde risk değerlendirme kontrol listesi ve Eker ve Kılıç (2021) tarafından 2014 yılında odun hammaddesi üretim işleri için geliştirilen çalışma alanı gözlem formu harmanlanarak bu form oluşturulmuştur. Veri-bilgi toplama amaçlı bu form; genel çalışma alanı etüdü, sağlık gözetimi ve hijyen, biyolojik etkenler, iklim koşulları, acil durumlar, eğitim ve sertifika, tehlikeli maddeler, fidan taşıma, fidan istifleme ve fidan dikimi işlerinde güvenli davranışlar, kişisel koruyucu donanım, elle kaldırma taşıma ve ergonomi, donanımsal iş araç gereçleri ile psikolojik ve sosyal etkenler konusunda özellikle araştırmacının gözlem ve sorgulamalarına dayalı olarak hem çalışanlar hem yapılan iş hem de iş ortamı hakkında bilgi toplama amaçlı olarak düzenlenmiştir. Arazi çalışmaları sırasında doğrudan gözlem, sormaca ve söyleşi yardımıyla, sahada doldurulmuştur.

Risk değerlendirme formu: Fidan dikimi işlerindeki tehlikeli durumları ve tehlikeli davranışları ve de bunlardan kaynaklanacak risk düzeyleriyle muhtemel önlemleri ortaya koyabilmek için kullanılması nispeten kolay olan L Tipi (5x5 Matris) Risk Değerlendirme tabloları (Acar ve Üçüncü, 2020), bilimsel gruplandırmaya göre yapılmış risk etmenleri listesi (fiziksel, kimyasal, biyolojik, psikolojik, ergonomik, ekolojik, finansal-ekonomik ve genel-siber güvenlik etmenleri) (Albayrak, 2020) ve çalışma alanı gözlem formundan yararlanılarak oluşturulmuş formdur ve toplanan veri-bilgi yardımıyla büro çalışmaları sırasında doldurulmuştur.

İSG açısından bir değerlendirme yapabilmek için çalışma ortamının, iş aktivitelerinin, tehlike-risk kaynaklarının, hareket analizinin ve risk değerlendirmesinin yapılması amacıyla aşağıda özetlenen yöntem izlenmiştir. Buna göre;

Öncelikle, Akdeniz Bölgesi ölçeğinde yürütülen fidan dikim işlerine fiilen katılan kadın iş gücü oranları hakkında bilgi toplanmıştır. Araştırma sahası ölçeğinde ise, kadın işçilerin demografik özellikleri, yapılan işin sebep olduğu sağlık problemleri ve kaygılarıyla ilgili bilgi edinmek için anket yöntemi (Kaptan, 1973) kullanılmıştır. Anket kapsamında; katılımcıların ad-soyad bilgisi istenmemiş, tanımlayıcı niteliklerine yönelik soru sorulmamış ve yüzlerini net şekilde gösteren fotoğrafları çekilmemiş ve/veya yayımlanmıştır. Böylelikle kişisel haklarına veya etik kurallara aykırı davranılmamıştır. Anketin uygulanması için işçinin dinlenme zamanı, yemek molaları, iş bitimindeki toparlanma anı, işe ulaşım sırası gibi çalışanı işinden alıkoymayacak zamanlarda anketin işçiye okunarak cevap vermesi beklenmiş, yönlendirme yapılmamaya özen gösterilmiştir. Bazı sorular, anketörün gözlemlerine dayalı 
olarak cevaplanacağından süreyi azaltabilmek için sorularda seçici davranılmıştır.

Fidan dikim işlerindeki iş öğelerinin belirlenmesi için işçilerin tekrar eden hareketleri, çalışma seyri ve çalışma sırasındaki duruşları (postür) izlenmiştir. İş akışı; iş adımlarına ve iş öğelerine ayrılarak hem çalışma yöntemine hem de çalışanın duruş ve davranışlarına göre tanımlanmaya çalışılmıştır. Ayrıca normal tempoda çalışan tecrübeli kadın işçilerden gönüllü olanlar, videoya kaydedilmiş ve hareket analizi yapılıp İSG açısından postür değerlendirmelerinin yapılabilmesi için depolanmıştır.

Çalışma alanı gözlem formuna; çalışma ortamının nitelikleri, çalışanların duruşları ve hareketleri, kullanılan araç gereçler ve her bir iş adımındaki elementel (temel) iş dilimindeki aktiviteler kaydedilmiştir. $\mathrm{Bu}$ form bir risk kontrol listesi olarak da kullanılmış; iş ortamından ve çalışandan kaynaklı tehlike ve risk faktörleri de işaretlenmiştir. Risk analizi (değerlendirmesi) için birçok yöntem olmasına karşın; bir değerlendiricinin yeterli olması, çok az dokümana ve veriye ihtiyaç duyması, kısa sürede ve kapsamlı şekilde uygulanabilmesi nedeniyle iş güvenliği mekanizması içerisinde yaygın olarak kullanılan risk değerlendirme metodu olan L tipi $(5 \times 5)$ matris yöntemi (Acar ve Üçüncü, 2020) tercih edilmiştir. Yöntemin temel adımları, aşağıda özetlenmiştir. Buna göre;

1. Tehlikelerin belirlenmesi: İş aktiviteleri, arazi gözlem formu, anket verileri ve de doğrudan ya da dolaylı gözlemler yardımıyla edinilen veri-bilgi incelenmiş, işverenin ve posta başlarının kişisel iletişimle ilettiği bilgiler de eklenerek çalışma ortamındaki tehlikeler ve riskler tanımlanmıştır. Sistematik ve anlaşılır bir tanımlama için bilimsel gruplandırmaya göre belirlenmiş risk faktörleri listesinden yararlanılmıştır. Fidan dikimi iş aşaması ölçeğinde; arazi gözlem formu ve risk etmenleri grup listesi dikkate alınarak tehlike kaynakları (tehlikeler; tehlikeli durumlar) ve riskler belirlenmiştir.

2. Risklerin derecelendirilmesi: Riskleri tanımlayabilmek için tehlike kaynağına bağlı riskin ortaya çıkma ihtimali (olasılık) ile çalışan sağlığına vereceği zararın/yaralanmanın şiddetinin bileşimi tespit edilmiştir. Burada "Risk=Olasilık (O) $x$ Şiddet (Ş)" formülünden yararlanılmıştır. Aşağıda Çizelge 3 ve 4 üzerinde gösterildiği gibi olasılık ve şiddet değerleri belirlenmiş, matris tipi risk değerlendirme formu ve risklerin derecelendirilmesi için sonuç skalası oluşturulmuştur (Çizelge 5).

İSG açısından bir değerlendirmede bulunabilmek için oluşturulan risk değerlendirme tablolarının sonuçları; Risk Düzeyi veya Risk Skoru/Eylem Tablosu oluşturularak irdelenmiş ve işlerin risklerinin kabul edilebilir seviyede olup olmadığı değerlendirilmiştir (Çizelge 6.). Tehlikelerin ortadan kaldırılması ya da risklerin kabul edilebilir düzeye indirilmesi için İSG mevzuatı uyarınca genel prensiplere uygun ve çeşitli çözüm yaklaşımlarının kavramsal çerçevesi (Eker ve Kılıç, 2021) içinde bazı tedbirler önerilmiştir.

Kadın çalışanların niteliklerinin tanımlanması için; boy ve kilo verilerinden yararlanılarak VKİ sonuçları (kilonun boy uzunluğun karesine bölünmesiyle $\left.\left(\mathrm{kg} / \mathrm{m}^{2}\right)\right)$ hesaplanmış ve Dünya Sağlık Örgütü'nün yayınladığı (HSGM, 2021) yetişkinler için VKİ tablosuna göre değerlendirilmiştir (Örneğin; VKİ:25-29.9 kg/m² ise kişi fazla kiloludur).

Çizelge 3. Riskin olasılı̆̆ının belirlenmesi

\begin{tabular}{lcl}
\hline Olasılık & Derecesi & Olasılık riskinin gerçekleşme sıklığ \\
\hline Çok düşük & 1 & Hemen hemen hiç \\
Düşük & 2 & Çok az (yılda bir kez) \\
Orta & 3 & Az (yılda birkaç kez) \\
Yüksek & 4 & Sıklıkla (ayda bir kez) \\
Çok yüksek & 5 & Çok (haftada birkaç kez/her gün) \\
\hline
\end{tabular}

Çizelge 4. Riskin şiddetinin belirlenmesi

\begin{tabular}{lcl}
\hline Şiddet & Derecesi & Riskin sonuçlarının etkileri \\
Çok hafif & 1 & $\begin{array}{l}\text { Çalışma saati kaybı yok, ilk yardım } \\
\text { gerektiren durum }\end{array}$ \\
Hafif & 2 & $\begin{array}{l}\text { Çalışma günü kaybı yok, ayakta tedavi } \\
\text { gerektiren kalıcı etkisi olmayan durum. }\end{array}$ \\
Orta & 3 & $\begin{array}{l}\text { Hafif yaralanmaya yol açan, yatarak } \\
\text { tedavi gerektiren durum. } \\
\text { C̈lüm, ciddi yaralanma, uzun süreli } \\
\text { tedavi gerektiren durum, meslek hastalı̆̆ }\end{array}$ \\
Çok ciddi & 5 & $\begin{array}{l}\text { Birden çok ölüm, sürekli iş göremezliğe } \\
\text { sebebiyet veren durum }\end{array}$ \\
\hline
\end{tabular}

Çizelge 5. L Tipi (5x5) Matris Risk Değerlendirmesi içerisinde R=OxŞ derecelendirmesi

\begin{tabular}{|c|c|c|c|c|c|}
\hline \multirow[b]{2}{*}{ OLASILIK } & \multicolumn{5}{|c|}{ ŞİDDET (SONUÇ) } \\
\hline & 1-ÇOK HAFİ & 2- HAFIF & 3-ORTA & 4-CİDDİ & 5-ÇOK CİDDİ \\
\hline 1-ÇOK DÜŞÜK & 1-Anlamsiz & 2-Düşük & 3-Düşük & 4-Düşük & 5-Düşük \\
\hline 2-DÜŞÜK & 2-Düşük & 4-Düşük & 6-Düşük & 8-Orta & 10-Orta \\
\hline 3-ORTA & 3-Düşük & 6-Düşük & 9-Orta & 12-Orta & 15-Yüksek \\
\hline 4-YÜKSEK & 4-Düşük & 8-Orta & 12-Orta & 16-Yüksek & 20-Yüksek \\
\hline 5-ÇOK YÜKSEK & 5-Düşük & 10-Orta & 15-Yüksek & 20-Yüksek & 25-Tolere Edilemez \\
\hline
\end{tabular}

Çizelge 6. L Tipi (5x5) Matris için risklerin derecelendirme skalası

\begin{tabular}{lll}
\multicolumn{1}{c}{ Skor } & Riskin seviyesi & Yapılması gerekenler \\
\hline $21-25$ & KABUL EDİLEMEZ RİSK & Tolere edilemez iş. Acil önlem alınmalıdır. İş süreci geçici olarak durdurulmalıdır. \\
$15-20$ & BELİRGİN RİSK & Acil önlem alınmalıdır. Riskler azaltılmadan çalışılmamalıdır. \\
$8-14$ & DİKKATE DEĞER RİSK & Önlem alınmalıdır. \\
$4-6$ & DÜŞÜK RİSK & Tolere edilebilir risk. Acil önlem ve ek kontroller gerektirmez. \\
$1-3$ & ÇOK HAFİ RİSK & Önlem faaliyeti gerektirmeyebilir \\
\hline
\end{tabular}


Ayrıca, iş akışı gözlem formu, arazi gözlem formu ve anket formlarındaki veri-bilgi yardımıyla her bir iş öğesinde, kadın çalışanların vücut duruşları basitçe -vücut şekli ve duruşuna göre analiz edilip değerlendirilmiştir. Bunun için OWAS (Ovako Working Posture Analyzing System; Ovako Çalışma Postürü Analiz Sistemi) (Enez, 2008; Koç ve Testik, 2016; Enez ve Nalbantoğlu, 2015) yönteminde kullanılan niteleme ve kodlamalardan yararlanılmıştır. Çalışanların sırt, kol ve bacak duruşları ile kaldırılan yük ve sarf edilen güce dayalı basit bir değerlendirme yapılmış; özellikle fidan dikim iş aşamasındaki yüklenme ve zorlanmalar değerlendirilmiştir. Elde edilen bulgular, risklerin değerlendirilmesi ve sonuçta İSG değerlendirmeleri için kullanılmıştır.

Yüz yüze görüşme metoduyla elde edilen ve arazide anket formuna aktarılan veri-bilgi; Microsoft Excel programına aktarılmıştır. Hazırlanan verilerin analiz edilip değerlendirilebilmesi için sınıflama ölçeğine dayalı sayısal kodlar yardımıyla bir kılavuz geliştirilmiştir. Her bir soru ve/veya soru grubu için frekans dağılımı ve yüzde analizi yapılmış ve değerlendirmede kullanılmıştır.

\section{Bulgular ve tartışma}

\subsection{A ̈̆açlandırma faaliyetlerinde fidan dikim işleri ve iş̧̧iliğ $i$}

Ağaçlandırma faaliyetleri kapsamındaki fidan dikim işlerinin; çalışanlar tarafından kolayca anlaşılabilir yapıda olduğu, sıralı ve karmaşık bir karar sürecini gerektirmeyen iş öğelerinden ibaret olduğu ve de basit el aletleri ile işin gerçekleştirilebildiği belirlenmiştir. Nitekim MYK' nin tanımladığ1 ulusal meslek standardına göre "Orman ağaçlandırma ve fidan yetiştirme işçisinin" mesleki yeterlilik seviyesi, sekizli seviye matrisi ölçeğine göre "Seviye (3)" olarak bildirilmiştir (MYK, 2021). Bu çerçevede fidan dikim işlerinin basit bilgi ve becerilerle kotarılabilecek işlerden olduğunu söylemek mümkündür.

Araştırma alanının da içinde bulunduğu Akdeniz Bölgesi'nde ağaçlandırma işlerinde çalışanların toplam ortalama \%65.5 oranında kadın çalışanlardan oluştuğu bulunmuştur. Araştırmanın gerçekleştirildiği Silifke Yöresi'nde kadın çalışanların oranı $\% 80$ olup bağlı bulunduğu Mersin Yöresi'nin ortalamasından (yaklaşık \%71) ve Akdeniz Bölgesi oranları ortalamasından daha fazladır. Bu durum, ağaçlandırma işlerinde yalnızca kadın çalışanlar üzerine odaklanılmasını destekleyen bir bulgu olarak değerlendirilmiştir.

Ağaçlandırmada fidan dikim işlerinde kadın işçi oranının fazla olmasının başlıca sebepleri: diğer ormancılık işlerine göre bu işlerin hafif olması, kadın istihdamı sağlanmaya çalışılması, erkeklerin alınan ücreti az bulması ve başka iş bulma imkânlarının olması, ağaçlandırma işleri sürekli iş olmadığı için kadınların eşlerinin arazide çalışmalarına razı olmaları ve en önemlisi kadınların ev ekonomisine katkı sağlayıp çalışma hayatında bulunmak istemeleri olarak belirtilmiştir.

İSG açısından genel bir değerlendirmenin yapılabilmesi için araştırmaya katılanların demografik özelliklerine yönelik bulgular Çizelge 7'de özetlenmiştir.
Çizelge 7. Katılımcıların demografik özelliklerinin frekans ve yüzde değerleri

\begin{tabular}{|c|c|c|c|}
\hline $\begin{array}{c}\text { Demografik } \\
\text { özellikler }\end{array}$ & Kategori & Frekans $(\mathrm{N})$ & Dağılım (\%) \\
\hline \multirow{6}{*}{ Yaş } & $18-25$ & 5 & 5.5 \\
\hline & $26-35$ & 17 & 18.7 \\
\hline & $36-45$ & 29 & 31.9 \\
\hline & $46-55$ & 23 & 25.2 \\
\hline & $56-65$ & 14 & 15.4 \\
\hline & $>65$ & 3 & 3.3 \\
\hline \multirow{4}{*}{ Medeni hal } & Evli & 76 & 83.5 \\
\hline & Bekar & 8 & 8.8 \\
\hline & Boşanmış & 1 & 1.1 \\
\hline & Dul & 6 & 6.6 \\
\hline Yaşanılan yer & Köy & 91 & 100 \\
\hline \multirow{4}{*}{ Çocuk sayısı } & 0 & 15 & 16.5 \\
\hline & $1-2$ & 39 & 42.8 \\
\hline & $3-4$ & 34 & 37.4 \\
\hline & 5-6 & 3 & 3.3 \\
\hline \multirow{5}{*}{ Eğitim } & Okur-yazar & 15 & 16.5 \\
\hline & değil & 48 & 52.7 \\
\hline & İlkokul & 9 & 9.9 \\
\hline & Ortaokul & 15 & 16.5 \\
\hline & $\begin{array}{c}\text { Lise } \\
\text { Üniversite }\end{array}$ & 4 & 4.4 \\
\hline \multirow{8}{*}{$\begin{array}{l}\text { Çalışma süresi } \\
\text { (y1l) }\end{array}$} & $<1$ & 7 & 7.7 \\
\hline & $1-4$ & 22 & 24.2 \\
\hline & $5-9$ & 26 & 28.6 \\
\hline & $10-14$ & 19 & 20.8 \\
\hline & $15-19$ & 9 & 9.9 \\
\hline & $20-24$ & 4 & 4.4 \\
\hline & $25-30$ & 3 & 3.3 \\
\hline & $>30$ & 1 & 1.1 \\
\hline \multirow{6}{*}{$\begin{array}{l}\text { Alınan ücret } \\
\text { (TL)/aylık }\end{array}$} & $<1000$ & 4 & 4.4 \\
\hline & $1000-1100$ & 65 & 71.4 \\
\hline & $1200-1300$ & 6 & 6.6 \\
\hline & $1400-1500$ & 9 & 9.9 \\
\hline & $1500-1600$ & 5 & 5.5 \\
\hline & $>2000$ & 2 & 2.2 \\
\hline \multirow{7}{*}{ Sigorta türü } & Yok & 51 & 56 \\
\hline & SSK & 12 & 13.2 \\
\hline & Bağkur & 6 & 6.6 \\
\hline & Yeşil kart & 12 & 13.2 \\
\hline & Dul maaşı & 5 & 5.5 \\
\hline & 65 yaş aylığı & 3 & 3.3 \\
\hline & Emekli sandığ 1 & 2 & 2.2 \\
\hline
\end{tabular}

Kadın çalışanların yarıdan fazlasının (\%57.1) 36-55 yaş aralığında yoğunlaşması, bu iş kolunda orta yaş ve üzeri kadınların yer aldığını işaret etmektedir. ISG açısından çalışanların yaşının; tehlike ve risklerin algılanmasında ve reaksiyon gösterilmesinde önemli bir gösterge (Acar ve Üçüncü, 2021) olduğu dikkate alınırsa, orta seviyeli risk potansiyelinden bahsedilebilir.

Eğitim durumu itibarıyla; okur-yazar olmayanların oranının \%16.5, ilkokul mezunlarının \%52.7, ortaokul mezunlarının \%9.9, lise mezunlarının $\% 16.5$ ve üniversite mezunlarının \%4.4 olduğu belirlenmiştir. Bu durum dikkate alındığında, henüz demografik bilgilere bakılarak kadın iş gücünün İSG alanındaki bilindik risklere açık olabileceğini söylemek mümkündür. Çünkü, Acar ve Eroğlu (2001), ormancılık işlerinde çalışanların eğitim düzeylerinin düşük olmasının iş veriminde ve servette kayıplar oluşturduğunu ve de iş kazalarını arttığını belirtmişlerdir.

Katılımciların yarısından fazlasının (\%56) herhangi bir sosyal güvencesi olmadığ belirlenmiştir. Sosyal sigorta ve Bağkur sahipleri, eş veya evlat durumundan faydalanmaktadır. Sosyal güvencesiz oluşlarının, kendilerinde güvensizlik hissi meydana getirdiğini ve 
oluşabilecek bir kazada zor duruma düşeceklerinin farkında olduklarını belirtmişlerdir. Nitekim bazı ormancılık işlerinde olduğu gibi kadın çalışanların kendi nam ve hesaplarına çalışmaları, iş akdinin olmaması ve buna bağlı sigortalı sayılmamaları, İSG kanunu kapsamı dışında kalmaları; yaşayacakları kazaların iş kazası olamayacağı ve bu nedenle sosyal güvencesiz çalıştıkları aşikardır.

Beden gücü ağırlıklı ve basit aletlerle yapılan işlerde iş gücünün çeşitli açılardan değerlendirilebilmesi için yapılan hesaplamada çalışanların VKİ ortalaması $27.5 \mathrm{~kg} / \mathrm{m}^{2}$ bulunmuştur. Acar ve Eker (2001b) tarafindan yapılan bir araştırmada da orman fidanlık işçilerinin VKİ değerlerinin (ortalama $25.7 \mathrm{~kg} / \mathrm{m}^{2}$ ) bu çalışma ile örtüştüğünü söylemek mümkündür. Kadın çalışanların \%70' inin fazla kilolu olması, ISG açısından hareketlerin kısıtlanmasını ve iş kazası risklerini barındırdığını ve ayrıca uzun süreli çalışmaları halinde mesleki hastalık riski içerdiğini de söylemek mümkündür. Buna göre, ergonomik risklere açık bir işçi kitlesi ile karşılaşıldığı anlaşılmaktadır.

İşçiler öğle yemeklerini hep birlikte ağaçlandırma sahasında, evlerinden getirdikleri ve aşçlık yapan işçinin yaptığı yiyeceklerle yemektedir. Çalışanların yarıya yakınının çay ve kahve tüketme alışkanlığı olmadığ1 belirlenmiştir. Katılımcılarının hiçbirinin alkol tüketim alışkanlığ 1 olmadığı; yalnızca \% 5 , inin sigara içtiği saptanmıştır. Öte yandan kitap okumak, televizyon izlemek, internette gezinmek, gezmek gibi kitle iletişiminin sağlanmasına ve yaygınlaşmasına yönelik kişisel ve sosyal aktivitelere katılım oranı da düşük bulunmuş; bu durum, özellikle İSG kültürü konusunda farkındalık oluşturacak yeterli altyapıya sahip olmadıklarını destekleyici bir bulgu olarak kaydedilmiştir.

Çalışanların hepsinin çalışma sahasına aynı araçla (midibüs) ulaşım sağladığ 1 ve ulaşımın ortalama 3 saat sürmesinden dolayı sabah 05.00'da yola çıkıp günlük en az 6 saat fiilen çalıştıkları belirlenmiştir Çalışanların tamamına yakını (\%94.5) hem çapa hem de bağ bıçağına sahip olup fidan dikim işi için bu aletleri kullanmaktadır.

Araştırmaya katılan kadınların iş kontrolleri ve fiziksel iş yükü açısından değerlendirilebilmesi için yöneltilen sorulara ait cevaplarında; tamamı mesleki (teknik) eğitim aldıklarını belirtmişlerdir. Ancak aldıkları eğitim, iş başı yapılmadan önce fidan dikim işinin nasıl yapıldığ 1 ile ilgili orman işletme çalışanı tarafından verilen eğitimdir. Bu eğitimler; genel iş tekniği bileşenlerini içeren tatbikat ve de alıştırmaların yapıldığı mesleki bir eğitim anlamına gelmemektedir. Nitekim mesleki yeterlilik kurumunun belirlediği Seviye-3 ölçütlerine (MYK, 2021) uygun bir eğitimin verilip verilmediği de tartışma konusu olabilir.

Araştırma sahasında yapılan doğrudan gözlemlerde tüm işçilerin iş akışının posta başı (işçilerin başında duran sorumlu kişi) ve orman işletme çalışanı tarafindan takip edildiği görülmüştür. Çalışma esnasında bir kontrolör tarafından sürekli izlenmek veya gerekli gereksiz uyarılmak, ağaçlandırma işinde psikolojik baskılara açık vaziyette çalışıldığını işaret etmektedir. İSG açısından bu davranışların, psikolojik risk etmenleri arasında sayılabileceğini söylemek mümkündür.

Doğrudan güvenlik ve sağlık özellikleriyle ilgili sorulara verilen cevaplar ve anketörün gözlemlerine ilişkin bulgular Çizelge 8'de verilmiştir.

Çizelge 8. Genel güvenlik ve sağlık özellikleri

\begin{tabular}{|c|c|c|c|}
\hline Sorular & Kategori & Frekans $(\mathrm{N})$ & Dağglım (\%) \\
\hline \multirow{2}{*}{ İşçi sağlığı ve iş güvenliği konusunda eğitim aldınız mı? } & Evet & - & - \\
\hline & Hayır & 91 & 100 \\
\hline \multirow{2}{*}{ Bu işi yaparken hiç kazaya uğradınız mı? } & Evet & 7 & 7.7 \\
\hline & Hayır & 84 & 92.3 \\
\hline \multirow{2}{*}{ İşçinin yanında yeterli ilk yardım malzemeleri var mı? } & Var & - & - \\
\hline & Yok & 91 & 100 \\
\hline \multirow{2}{*}{ İşyerinde ilk yardım malzemeleri var mı? } & Var & - & - \\
\hline & Yok & 91 & 100 \\
\hline \multirow{2}{*}{ İşçiler sürekli sağlık problemlerinden yakınıyor mu? } & Evet & 38 & 41.7 \\
\hline & Hayır & 53 & 58.3 \\
\hline \multirow{2}{*}{ Bel ağrılarından şikayetleri var mı? } & Evet & 55 & 60.4 \\
\hline & Hayır & 36 & 39.6 \\
\hline \multirow{2}{*}{ Sert omuz-kürek kemiği ağrılarından şikayetçiler mi? } & Evet & 26 & 28.6 \\
\hline & Hayır & 65 & 71.4 \\
\hline \multirow{2}{*}{ İşçinin hareketlerini kısıtlayııı bir rahatsızlığı var mı? } & Var & 34 & 37.4 \\
\hline & Yok & 57 & 62.6 \\
\hline \multirow{2}{*}{ İşçide çalışmaktan dolayı bir rahatsızlık oluşmuş mu? } & Evet & 28 & 30.8 \\
\hline & Hayır & 63 & 69.2 \\
\hline \multirow{2}{*}{ İşçi çalışmaya bağlı bir hastalığa maruz kalmış mı? } & Evet & 3 & 3.3 \\
\hline & Hayır & 88 & 96.7 \\
\hline \multirow{2}{*}{ İşçide psikolojik rahatsızlık göstergesi-şikâyeti var mı? } & Evet & 28 & 30.8 \\
\hline & Hayır & 63 & 69.2 \\
\hline \multirow{2}{*}{ İşçi yeterli medikal bakımdan geçirilmekte mi? } & Evet & - & - \\
\hline & Hayır & 91 & 100 \\
\hline \multirow{2}{*}{ İşçi (kadın olmanın getirdiği) kişisel sağlık problemlerinden dolayı çalışmadığı olmuş mu? } & Evet & 4 & 4.4 \\
\hline & Hayır & 87 & 95.6 \\
\hline
\end{tabular}


ISG konusunda katılımcıların hiçbirinin eğitim almadığı belirlenmiştir. Bununla beraber çalışanların \%94,5'i, 6331 sayılı İş Sağlığı ve Güvenliği Kanunu'ndan, \%100’ü ise Orman İşlerinde İş Sağlığı ve Güvenliği kılavuzundan habersiz olduklarını bildirmiştir. İşçilerin \%7.7'si iş esnasında veya ulaşımda kaza geçirdiğini aktarmıştır. Araştırmaya katılanlardan dört işçi işe ulaşım esnasında şoför dikkatsizliği sebebiyle kaza yaptıklarını bildirmiştir. Bir işçi ise işi yetiştirebilmek için hızlı çalıştığı esnada bağ bıçağı ile fidanı polietilen torbadan ayırma işleminde elinde eldiven olmadığı için parmağının derisine zarar verdiğini söylemiştir. Öte yandan çalışanlardan ikisi iş esnasında dikkat dağınıklığının da etkisiyle eğimli arazide kayıp el bileklerinde burkulma-incinme hasarını yaşadıklarını belirtmişlerdir. Çalışma duruşları kas-iskelet sistemini etkilemekte ve uygun olmayan çalışma duruşuyla birlikte iş kazaları kaçınılmaz olmaktadır (Karwowski ve Marras, 1999). Aynı sektör içindeki fidanlıklarda; Göl (2018), mevsimlik işçilerle ilgili yaptığı çalışmada, katılımcıların \%47'sinin en az bir defa iş kazası geçirdiğini ve bu kazaların; \%36'sının kayıp düşme sebebiyle olduğunu ortaya koymuştur. Bu araştırmada, 7 işçiden 4'ü dikkatsiz davranış sergilediğinden dolayı iş kazası geçirmiştir. Araştırmaya katılan toplam çalışan kitlesi içinde yaklaşık \%8' lik kaza vakasının olduğu belirlenmiştir. Ancak çalışanların iş kazası ve kazanın ne anlama geldiği konusundaki algıları veya kazaya maruz kalmaları durumundaki tutumları tam belirgin olmadığından veya bu anketle ölçülemediğinden hem hafif kazaların hem de ramak kala olaylarının daha sık olduğunu iddia etmek mümkündür.

İşçilerin hiçbirinde ilk yardım malzemesi bulunmadığı belirlenmiştir. İşveren tarafından da temin edilmiş ve iş yerinde kullanılabilir ilkyardım çantasına rastlanmamıştır. En yakın sağlık kuruluşu veya yerleşim yeri dikkate alındığında ağaçlandırma işlerinde meydana gelebilecek herhangi bir kaza için ilkyardım malzemelerinin bulundurulmayışı önemli bir eksiklik olarak görülmüştür. Doğa koşullarında yalnızca kazalar değil, çeşitli hayvan ısırma veya sokmaları, zehirli bitkilerle temas, vb. olumsuzlukların yaşanması muhtemeldir. Ağaçlandırma işlerinin yapıldığı bu sahada, İSG gerekliliklerinin yeterince dikkate alınmadığı anlaşılmaktadır.
Bununla birlikte ișçilerin \%41.7'si sürekli sağlı problemlerinden, \%60.4'ü bel ağrısından, \%28.6'sı sert omuz veya kürek kemiği ağrısından, \% 6.6'sı varis-damar rahatsızlığından (60 yaş üzerinde görülmüştür), \%37.4'ü kısıtlayıcı rahatsızlıklardan (bunların \%2.9'u sirt ağrısı, \%26.5'i omuz-boyun ağrıs1, \%70.6's1 da kol-bacak ağrıs1), \%30.8'si çalışmaktan dolayı oluşan rahatsızlıklardan (bunların \%3.6's1 parmakta beyazlık, \%96.4'ü halsizlik), \%3.3'ü çalışma süresince nefes darlığından yakınmıştır. Çalışanlara psikolojik rahatsızlıkları olup olmadığı sorulduğunda \%30.8'i evet cevabını vermiştir ve bu cevapların \%7.1'i dalgınlık, \%3.6's1 asabiyet, \%60.7'si uyuma zorluğu, \%28.6'sı ise sinirsel baş ağrısı şeklinde nitelendirilmiştir. Çalışanların bu yakınmalarının; sadece ağaçlandırma işlerinden kaynaklandığını söylemek mümkün olmayabilir. Ancak, iş akışı ve çalışanların iş sırasındaki vücut duruşları dikkate alındığında bel ağrıları, el-kol ağrıları ve sırt ağrılarından yakınmaları olağan görünmektedir. Bununla birlikte, çalışanların henüz iş başlangıcında ve devamında herhangi medikal bir kontrolden geçirilmediği belirlenmiştir. Dolayısıyla işin çalışanlara veya çalışanların işe uyumuna ilişkin bir denetimin yapılmadığı ortadadır. İSG' nin sağlanması için ergonomik açıdan çalışan-iş uyumuna ilişkin bir değerlendirmenin yapılamamış olması; ağaçlandırma işlerinde sağlı ve güvenliğe yeterli hassasiyetin gösterilmediğini işaret etmektedir.

Çalışanların güven içinde ve sağlıkla çalışabilmeleri; iş yerinin ve işyerine ulaşılabilirliğin güvenli olmasına bağlıdır (Acar ve Üçüncü, 2020). Çalışanların (kendilerine sorularak) ve işyerinin (anketörün gözlemiyle) güvenlik durumu ile ilgili bulgular Çizelge 9' da özetlenmiştir.

Katılımcıların hiçbiri çalışma sahasına erişim için, saha içinde de hareket ve de geçiş yolları için herhangi uyarı işaretlerinin kullanılmadığını, ancak çalışılacak yeri, yöreye hâkim oldukları için bulmakta ve burada hareket etmekte zorluk yaşamadıklarını dile getirmişlerdir. $\mathrm{Bu}$ alanda ağaçlandırma işleri için uyarı ve işaret levhalarının kullanılmaması, ISG açısından bir zafiyet olduğunu işaret etmektedir.

Çizelge 9. Çalıșan ve işyeri güvenlik durumu

\begin{tabular}{|c|c|c|c|}
\hline Sorular & Kategori & Frekans $(\mathrm{N})$ & Dağılım $(\%)$ \\
\hline \multirow{2}{*}{ İşçilerin çalışma yerleri ve geçiş yolları uyarı işaretleriyle açıkça belirtilmiş mi? } & Evet & - & - \\
\hline & Hayır & 91 & 100 \\
\hline \multirow{2}{*}{ İşçinin iş esnasında durduğu yer güvenli mi, kayma riski var mı? } & Evet & 5 & 5.5 \\
\hline & Hayır & 86 & 94.5 \\
\hline \multirow{2}{*}{ İşçinin çalışma yeri, işçinin kolayca ve serbestçe hareketine uygun mu? } & Evet & 85 & 93.4 \\
\hline & Hayır & 6 & 6.6 \\
\hline \multirow{2}{*}{ Makine ve aletlerin tehlikeli kısımları yeterince korunuyor mu? } & Evet & 91 & 100 \\
\hline & Hayır & - & - \\
\hline \multirow{2}{*}{$\begin{array}{l}\text { İş yerinde zorunlu ihtiyaçları karşılama (tuvalet, duş) ve temizlik şartları var mı, uygun } \\
\text { mu? }\end{array}$} & Evet & - & - \\
\hline & Hayır & 91 & 100 \\
\hline \multirow{2}{*}{ İş yerinde alet ve ekipmanları koruyucu, malzemeleri depolayıcı barakalar var mı? } & Evet & - & - \\
\hline & Hayır & 91 & 100 \\
\hline \multirow{2}{*}{ Makine ve aletler düzenli olarak bakımdan geçiriliyor mu? } & Evet & 70 & 76.9 \\
\hline & Hayır & 21 & 23.1 \\
\hline \multirow{2}{*}{ Alana işle ile ilgili sağlık ve güvenlik işaretleri (uyarı levhaları) yerleştirilmiş mi? } & Evet & - & - \\
\hline & Hayır & 91 & 100 \\
\hline \multirow{2}{*}{$\begin{array}{l}\text { Isıran ya da sokan yabani hayvanlara (kene, ayı, yılan, arı vb.) karşı işveren ya da işçi } \\
\text { tarafından önlem alınmıș mı? }\end{array}$} & Evet & 62 & 68.1 \\
\hline & Hayır & 29 & 31.9 \\
\hline
\end{tabular}


Çalışanların $\% 5.5^{\prime} \mathrm{i}$ iş yaparken bulundukları alanın eğimli olmasına bağlı olarak kayma riski yaşadığını, \%6.6'sı ise çalışma yerinin kolayca ve serbestçe harekete uygun olmadığını belirtmiştir. Eğimli, taşlık, girintili çıkıntılı ve özellikle arazi hazırlığından sonra açılan teraslar boyunca taş parçaları ve keseklerin olması çalışanların iş sırasındaki duruşlarını etkilemektedir. Ancak, çalışanların bu durumu ve çalışma duruşlarını kanıksamış olsa gerek ki çoğunluğu, arazi şartlarından etkilenmediklerini ifade etmiştir. Çalışanların birbirlerine göre olan aralık mesafeleri çapa sallama, eğilme-kalkma, ileri doğru uzanma vb. açıdan rahat hareket etmelerini sağladığından yani bir nevi süpürme mesafesinin yeterli olmasindan dolayı hareket kabiliyetlerinde (fiziksel ergonomi açısından) engelleyici unsurun olmadığını rivayet etmişlerdir.

Çalışanların kullandığı bağ bıçağı ve dikim çapası; kesici ve hatta delici niteliktedir. Bağ bıçakları, kullanılmadıklarında, kendi sapları içinde muhafaza edilebildiğinden taşınması ve depolanması kolaydır. Ancak kullanım sırasında tırtıklı (testere dişli) ağız açıklığının bağ bıçakları için bir risk oluşturduğunu söylemek mümkündür. Çalışanlar, bu aleti kullanılırken eldiven giydikleri için tehlike ve risklerden korunduğunu ifade etmiştir. Ancak kullanılan eldiven; tozdan kirden koruma sağlayabilir nitelikte ancak kesilmelere ve delinmelere karşı koruyucu özellik taşımamaktadır. Ağaçlandırma faaliyetlerinde kişisel koruyucu donanımlardan en önemlisinin eldiven olduğu söylenebilir. Eldiven çeşitleri (Starline, 2021) itibarıyla; fidan dikim işlerinde EN 388 ve EN 374 niteliğindeki eldivenlerin, kadın çalışanlar için uygun olacağı söylenebilir.

Çapalar için de eldiven, tutma kolaylığı sağlasa da çapanın hem çalışanın kendine hem de yakınında çalışan diğer çalışanlara çarpma ve kesme tehlikesi-riski bulunmaktadır. Çapalar, taşınırken ve depolanırken (kullanılmadığında bir arada tutulurken) kesici uç için herhangi koruyucu kullanılmamaktadır. Bununla birlikte, işçilerin tamamı iş yerinde alet ve ekipmanları koruyucu, malzemeleri depolayıcı barakalar olmadı̆̆ını belirtmiştir. Kullanılan aletler işçiler tarafından tedarik edilmektedir ve her gün işe geliş gidişlerinde beraberinde taşınmaktadır. Çalışanların \%76.9'u aletleri bakımdan geçirdiğini, \%23.1'i gerekli bütçeleri bulunmadığı ve özen gösteremediklerini için bakım yapmadıklarını belirtmiştir.

Yapılan iş dağlık alanda arazi çalışması olduğundan tuvalet, duş kabini gibi ayrılmış veya sahada imal edilmiş bir alan yoktur. Hem temizlik hem de içme-kullanma (yemek yapımı vb.) suyu işçiler tarafından beraberlerinde bidonlar içinde işyerine getirilmektedir. $\mathrm{Bu}$ nedenle özellikle kadın çalışanlar için işyerinde kişisel hijyen probleminin yaşandığı söylemek mümkündür. Kişisel ve işyeri hijyeni, işyerinde İSG' nin sağlandığının bir göstergesi olabilecek niteliktedir (Albayrak, 2020).

Araştırma alanında çalışan işçilerin \%68.1'i ısıran ya da sokan yabani hayvanlardan (kene, ayı, yılan, arı vb.) kaynaklanabilecek rahatsızlıklara karşı ne kendileri tarafından ne de işveren tarafindan herhangi bir önlem alınmadığını belirtmiştir. Nitekim işyerinde gerek ilkyardım malzemelerinin olmayışı gerekse çalışanların giyim kuşamları bu durumu destekler niteliktedir. Kadın çalışanların uzun, vücudu açıkta bırakmayacak şekildeki yöresel kıyafetleri giydikleri gözlemlenmiş ve kendileri de yaz kış fark etmeksizin bu kıyafetlerle çalıştıklarını söylemiştir.

Kişisel koruyucu donanımlar konusunda da; çalışanların yalnızca eldiven kullandıkları belirlenmiştir. Çalışanlar, iş aletlerinde olduğu gibi koruyucu kişisel donanımlarını da kendileri tedarik etmektedir. Öte yandan, ağaçlandırma işleri; toz maskesi, gözlük, güvenli ayakkabı ve güvenli giysilere ihtiyacı gerektirecek potansiyele sahiptir. Kişisel koruyucu donanım, risk etmenlerini minimuma indirmede yardımcı olabilme kapasitesine sahiptir (Kaya ve Özok, 2018). Eroğlu vd. (2010), fidanlık işçileriyle yaptıkları çalışmada işçilerin kişisel koruyucu araçlar konusunda bilgili olmadıklarını ortaya koymuşlardır. Göl (2018), fidanlık işçileriyle yaptığ kişisel koruyucu araçlardan faydalanmadıklarını belirtmiştir. Araştırma sahasında yalnızca eldiven kullanılması ve bu donanımın da yeterli nitelikte olmaması, risklerden kaçınma hiyerarşisi açısından son aşamanın dahi yeterince yerine getirilemediğini göstermektedir.

İşçilerin genel olarak çalışmaktan kaynaklanabilecek psikolojik problemlerini belirlemek ve bu yöndeki risk etmenlerini ortaya koyarak çalışanların bu işe karşı algı tutum ve beklentilerini saptayabilmek amaciyla yöneltilen sorulara verilen cevaplara ilişkin bulgularda; çalışanların \%32.9'u kendisini çalışmaktan dolayı uykulu hissetmekte, \%41.7'si sabah uyandığında kendini yorgun, \%37.3'ü ise bazen vücudunu taşıyamayacak kadar halsiz hissettiğini, \%19.7'si kendisini sağlıksız ve hastalıklı, \%28.5'i mutlaka vücudunun bir yerinde ağrı olduğunu dile getirmiştir. Katılımcıların \%54.9'u çok fazla enerji harcadığını belirtirken \%40.6'sı çalıştığı dönemde kilo kaybı yaşadığını söylemiştir. \%19.7'si iş sonrasında yorgunluğunu atamazken, \%25.2'si iş sırasında kendisini yorgun hissedip uyumak istediğini belirtmiştir. Kadın işçilerin \%79.1'i kendilerine zaman ayıramadıklarını, bunun sebebi olarak da iş sonrasında zamanlarının olmadığını, arta kalan zamanlarda da ev işleriyle ve çocukların bakımıyla uğraştıklarını dile getirmişlerdir.

\subsection{Risklerin değerlendirilmesi}

Fidan dikiminde çalışan kadınların, katlandıkları iş yükünün etkilerini ortaya koymak ve eylemlerini ergonomik riskler açısından değerlendirmek için iş dilimleri ölçeğinde OWAS yöntemine göre yapılan hareket/eylem analizi bulguları Çizelge 10'da özetlenmiştir.

Fidan dikiminde; çömelerek dizler kıvrık vaziyette ve de öne eğilerek eğimli arazide dengede durup çalışmanın getirdiği fizyolojik bir iş yükünden bahsedilebilir. Çünkü vücut postürü bu durumdayken ergonomi ilkelerinin (Üçüncü ve Acar, 2020) ilk kurallarından biri olan vücudun $\mathrm{S}$ biçiminin korunması ihlal edilmektedir. Katlanmış, kıvrılmış ve zamanla torsiyona (burkulmuş/bükülmüş) uğrayan vücut hızla yorulmaya ve sonuçta iş yükünün artmasına neden olma potansiyeline sahiptir.

Ağaçlandırma işlerindeki bedensel işgücü kullanımının yoğun olduğu fidan dikim aşamasında vücut postürünün sırt, kol, bacak eylemleri üzerinden yapılan değerlendiremeye göre; fidan yerleştirme ve fidan çukuruna toprak atılması işlerinde iş yüklenmesi ve zorlanmanın çok fazla olduğu ve acele ergonomik düzenleme yapılmasını gerektirecek nitelikte olduğu belirlenmiştir. Diğer iş dilimlerinde ise zorlanma derecesinin düşük olduğu ve uzun vadede 
ergonomik düzenlemelerin yapılması gerektiği bulgusuna erişilmiştir. Öte yandan bu çalışmada, çalışma duruşlarının analizine yönelik olarak ergonomik risk etmenlerini tanılayabilmek için bir nevi basit bir değerlendirme yapılmaya çalışılmıştır. Hareketler ve bunların yapılıştekrarlanış sürelerine ilişkin bir çalışma ve değerlendirme yapılmamıştır. Literatürde ise, çalışma duruşları konusunda çeşitli değerlendirme yöntemlerine (Akay vd., 2003; Can ve Fığlalı, 2014; Ünver-Okan ve Acar, 2017; Kee, 2021) rastlamak mümkündür. Uygunsuz çalışma duruşlarının, iş̧̧i üzerinde; stres, yorgunluk ve kas iskelet sistemi rahatsızlıkları oluşturduğu ve meslek hastalıkları riskini arttırarak iş veriminde azalmaya neden olduğu bilinmektedir (Ünver-Okan ve Kaya, 2015).

Anket bulguları, çalışma alanı gözlem formu, iş analizi ve hareket analizi bulgularıla risk etmenleri ölçeğinde, risk değerlendirme tablosu Çizelge 11'de özet olarak verilmiştir.

Ergonomik açıdan risk faktörleri uygun olmayan duruş, uygulanan veya maruz kalınan kuvvet, tekrarlı hareketler ve zorlanmalara karşı süreklilik (Albayrak, 2020) şeklinde sıralandığında; fidan dikim işlerinde, iş akışı gereği çalışanların kısa süreli de olsa uygun olmayan duruşlarla çalıştıkları görülmüştür. İşçiler, tüplü sedir fidanlarından (800-1300 g/fidan), dikim için yanlarında (heybe adı verilen sırta ask1lı çantalarda) genelde 3-4 fidan birlikte taşınmaktadır ve toplam fidan ağırlığ en fazla $3-5.5 \mathrm{~kg}$ arasında değişmektedir. Çapa ve bağ bıçağı ile birlikte çalışma sırasındaki ağırlığın 10 kg' 1 aşmadığ 1 söylenebilir. Çapayla; toprağın kazılması, kazılan toprağın çekilerek veya itilerek fidan çukuruna form verilmesi sırasında kuvvet uygulanmaktadır. Bağ bıçağı ile fidan tüplerinin diplerinin kesilmesinde de çapalamaya nispeten daha düşük bir kuvvet uygulanmaktadır. Bir işçinin fidan dikimi için 59-85 saniye içinde eğilme-eğilip kalkma-kıvrık bükük formda hareketçömelme gibi hareketleri tekrarladığı belirlenmiştir. En çok zorlanmanın fidan yerleştirme ve toprak atımında olduğu bilindiğinden kısa süreli tekrarlı hareketlere bağlı bu zorlanmaların işçiler tarafından tolere edilebildiği görülmüştür. Çünkü işyerinde verimli çalışma zamanı 6 saat kabul edildiğinde bu süre zarfında bu işlerin yapılabildiği ve ertesi günlerde de aynı tempo ve performansta, iş bitene kadar gerçekleştirildiği dikkate alındığında ergonomik açıdan fidan dikim işinin tüm zorluğuna ve ergonomik risklerine nazaran yapılabilir bir iş olduğu söylenebilir.

Çizelge 10. Fidan dikiminde işçi hareketlerinin değerlendirilmesi

\begin{tabular}{|c|c|c|c|c|}
\hline \multirow{2}{*}{$\begin{array}{l}\text { Vücut postürü } \\
\text { İş Dilimi* }\end{array}$} & \multicolumn{3}{|c|}{ Duruş-Durum } & \multirow{2}{*}{ Eylem sınıfı ve açıklaması } \\
\hline & Sirt & Kollar & Bacaklar & \\
\hline Çukur açma & Eğik ve kıvrık & $\begin{array}{l}\text { Omuz seviyesinin } \\
\text { altında }\end{array}$ & $\begin{array}{l}\text { Dizler düz iki bacak } \\
\text { üstünde dikilme }\end{array}$ & $\begin{array}{l}\text { Zorlanma fazla değil. Yakın zamanda } \\
\text { ergonomik düzenleme yapılmalıdır. }\end{array}$ \\
\hline $\begin{array}{l}\text { Fidanı alma ve dip } \\
\text { kesimi }\end{array}$ & Kıvrık-bükülük & $\begin{array}{l}\text { Omuz seviyesinin } \\
\text { altında }\end{array}$ & $\begin{array}{l}\text { Dizler düz iki bacak } \\
\text { üstünde dikilme }\end{array}$ & $\begin{array}{l}\text { Normal duruş. Ergonomik düzenleme } \\
\text { gerekmeyebilir. }\end{array}$ \\
\hline Fidan yerleştirme & Eğik ve kıvrık & $\begin{array}{l}\text { Omuz seviyesinin } \\
\text { altında }\end{array}$ & $\begin{array}{l}\text { İki dizde kıvrık ve yere } \\
\text { çökülmüş }\end{array}$ & $\begin{array}{l}\text { Yüklenme ve zorlanma çok fazla. Derhal } \\
\text { ergonomik düzenleme yapılmalıdır. }\end{array}$ \\
\hline Toprak atımı & Eğik ve kıvrık & $\begin{array}{l}\text { Omuz seviyesinin } \\
\text { altında }\end{array}$ & $\begin{array}{l}\text { Dizler bükülmüş iki } \\
\text { bacak üstünde dikilme }\end{array}$ & $\begin{array}{l}\text { Yüklenme ve zorlanma çok fazla. Derhal } \\
\text { ergonomik düzenleme yapılmalıdır. }\end{array}$ \\
\hline Sıkıştırma & $\begin{array}{l}\text { Düz ama kısmen } \\
\text { öne yana eğilmiş }\end{array}$ & $\begin{array}{l}\text { Omuz seviyesinin } \\
\text { altında }\end{array}$ & $\begin{array}{l}\text { Dizler dik ve iki bacak } \\
\text { üstünde dikilme }\end{array}$ & $\begin{array}{l}\text { Zorlanma fazla değil. Yakın zamanda } \\
\text { ergonomik düzenleme yapılmalıdır. }\end{array}$ \\
\hline Teras formu verilmesi & Eğik ve kıvrık & $\begin{array}{l}\text { Omuz seviyesinin } \\
\text { altında }\end{array}$ & $\begin{array}{l}\text { Dizler dik ve iki bacak } \\
\text { üstünde dikilme }\end{array}$ & $\begin{array}{l}\text { Zorlanma fazla değil. Yakın zamanda } \\
\text { ergonomik düzenleme yapılmalıdır. }\end{array}$ \\
\hline Taşla sabitleme & Eğik ve kıvrık & $\begin{array}{l}\text { Omuz seviyesinin } \\
\text { altında }\end{array}$ & $\begin{array}{l}\text { Dizler dik ve iki bacak } \\
\text { üstünde dikilme }\end{array}$ & $\begin{array}{l}\text { Zorlanma fazla değil. Yakın zamanda } \\
\text { ergonomik düzenleme yapılmalıdır. }\end{array}$ \\
\hline
\end{tabular}

*İş dilimlerinde; yük/güç gereksinimi 10 kg' ın altındadır.

Çizelge 11. Risklerin genel değerlendirme tablosu

\begin{tabular}{lcc}
\hline Değerlendirilen etkenler & Risk skoru & Risk düzeyi \\
\hline 1. Genel çalışma ve çalışma alanı etüdü & 10 & ORTA \\
2. Sağlık gözetimi ve hijyen & 12 & ORTA \\
3. Biyolojik riskler & 12 & ORTA \\
4. İklim koşulları & 11 & ORTA \\
5. Acil durumlar & 19 & YÜKSEK \\
6. Eğitim ve bilgilendirme & 11 & ORTA \\
7. Tehlikeli maddeler & 8 & ORTA \\
8. Dikim çukur açmada güvenli davranışlar & 9 & ORTA \\
9. Dip kesiminde güvenli davranışlar & 11 & ORTA \\
10. Fidan yerleştirmede güvenli davranışlar & 12 & ORTA \\
11. Toprak atmada güvenli davranışlar & 12 & ORTA \\
12. Sikıştırmada güvenli davranışlar & 3 & DÜŞÜK \\
13: Teras formu vermede güvenli davranışlar & 15 & YÜKSEK \\
14. Taşla sabitlemede güvenli davranışlar & 12 & ORTA \\
15. Kişisel koruyucu donanım & 12 & ORTA \\
16. Elle kaldırma taşıma ve ergonomi & 9 & ORTA \\
13. Donanımsal iş araç gereçleri & 11 & ORTA \\
14. Psikolojik ve sosyal etkenler & 9 & ORTA \\
\hline
\end{tabular}




\section{Sonuç ve öneriler}

Çoğunlukla dağlık, engebeli ve merkezi yerleşim yerlerinden uzak sahalarda gerçekleştirilmekte olan ağaçlandırma faaliyetleri kapsamındaki fidan dikim işleri, doğrudan beden gücü kullanımıyla gerçekleştirilen işlerdendir. $\mathrm{Bu}$ işlerde, örneğin Akdeniz Bölgesi'nde çoğunlukla (\%65.5 oranında) kadın iş gücünden yararlanılmaktadır. Bu saha içinde de Mersin Yöresi genelinde ve araştırma alanı özelinde kadın iş gücünün ağaçlandırma işlerindeki rolü; sırasıyla $\% 80$ ve $\% 71.3$ ' lük oranlardadır. Kadınlar, ağaçlandırma işlerinde çoğunlukla dikime hazırlık, dikim ve çapa-ot alma iş aşamalarına katılmaktadır. İş̧ sürekliliğinin olmaması, gündelik çalışmaya uygun olması ve kalifiye iş̧̧ilik gerektirmemesi gibi nedenlerden dolayı, ağaçlandırma işlerinde kadın iş gücü etkin olarak yer almaktadır.

Araştırma alanı ölçeğinde, ağaçlandırma işlerinde çalışan kadınların yarıdan fazlasının (\%57.1) yaşları 36-55 aralığında olup bu işlere katılan kadın iş gücünün orta yaş ve üzeri gruba dahil olduğu ortaya konulmuştur. Ağaçlandırma işlerinde çalışacaklar için ergonomik açıdan bir ön değerlendirme veya eleme yapılmadığı gibi çalışanların kendisi tarafından da işe uygunlukları konusunda bir değerlendirme yapılmamaktadır. Araştırmaya katılanların yarısından fazlasının (\%50.55) fazla kilolu olması çalışma ergonomisi açısından fiziksel bir uyumsuzluğun olduğunu göstermektedir.

Ulusal mesleki yeterlilik standardı olmasına rağmen halihazırda ağaçlandırma işlerinde, bu belgeye ihtiyaç duyulmadan çalışılmaktadır. Ağaçlandırma işçileri iş tekniği konusunda ve İSG konusunda herhangi bir eğitim görmeksizin çalışmaktadır. Çoğunluğunun İSG konusunda hiçbir bilgisi bulunmamaktadır. İş başlangıcı ve sürecinde de ağaçlandırma işini yapmalarından dolayı hiçbir çalışan sağlık gözetiminden geçirilmemektedir. İş hijyeni ve kişisel hijyen bakımından da hem eğitim verilmemiş hem de işveren ve işçiler tarafindan gerekli işyeri tedbirleri alınmamıştır. Aşırı sıcak, aşırı soğuk, yağmur vb. durumlarda çalışanların korunmasına/barınmasına yönelik önlemlere de rastlanmamaktadır.

Ağaçlandırma işlerinin kadın iş gücünün yoğunlaştığ dikim aşamasında, çoğunlukla basit el aletleri kullanılmakta olup bağ bıçağı ve çapa en çok kullanılan donanımlardır. Kesme, delme, çarpma gibi tehlikeleri ve riskleri bulunan donanımlara ilişkin fazlaca kaza hikayesine rastlanmamıştır. $\mathrm{Bu}$ durum, bu aletlerin ya dikkatli kullanıldı̆̆ 1 ya da vücuttan uzakta iş yapılmasına bağlı olarak kazalara neden olma sıklığının düşük olduğunu göstermiştir. $\mathrm{Bu}$ açıdan diğer bulgularla birlikte fidan dikim işlerinin az tehlikeli işler kategorisinde değerlendirilebileceği söylenebilir.

Ağaçlandırma işlerinde çalışanlar kendi nam ve hesaplarına çalışmaları, bir iş akdinin bulunmaması ve sigortalılık halinin oluşmamasından dolayı bu işlerde meydana gelen kazalar iş kazası niteliğinde değildir. Ağaçlandırma işlerinde bildirilen kazaların basit ve geçici yaralanmalarla sonuçlandığı görülmektedir. Bununla birlikte ağaçlandırma işleri fiziksel ve fizyolojik olarak çalışanı zorlayan ve yoran bir iş tekniğine sahip olmasından dolayı çalışanlarda çeşitli sağlık problemleri oluşabilmektedir. İşin tüm yıl boyunca ve uzun yıllarca devamlılık göstermemesi ve çalışanların periyodik olarak sürekli bu iş kolunda yer almamaları meslek hastalığı oluşumu açısından bir sonuca erişilmesini güçleştirmiştir.
Hava hallerine bağlı olarak termal konfor şartları, aydınlatma ve basınç gibi iklim koşullarına bağlı açık etkiler ve risk etmenleri mevcuttur. Toprakla temas halinde olunmasindan dolayı toz, duman, vb. fiziko-kimyasal etkilerle karşılaşılmaktadır. Bitkilerle ve bitki köklerini kapsayan yetiştirme tüpleriyle temas sırasında böcek, mantar, bakteri, virüs ve parazitlerle de temas edilebildiğinden biyolojik risk faktörlerine açık bir işçilik yapılmaktadır. Çalışma postürü göreceli olarak değerlendirildiğinde; vücut sürekli ikiye katlanmış vaziyette, zaman zaman bacaklar katlanmış olarak sürekli öne eğilme ve kıvrılmış durumda çalışılmaktadır.

Genel olarak değerlendirildiğinde, fidan dikim süreci az tehlikeli işler sınıfında yer almaktadır. Çalışma ortamının izole olması ve merkezi yerleşim yerleri ile sağlık merkezlerine uzak olması hem iş süresinin verimsizliğine hem de kaza risklerine karşı, kendisi bir risk olmaktadır. Çalışanların teknik ve iş sağlığı güvenliği açısından eğitimsiz olmaları da bir risk potansiyeli oluşturmaktadır. İşlerin kesici ve delici aletlerle sürdürülüyor olması ve doğaya açık alanda çalışılıyor olması çalışma ortamının tehlikeli durum ve risklere açık olduğunu göstermektedir. $\mathrm{Bu}$ ortamda doğal afetler olması halinde, yangın, hayvanböcek 1sırması, iş kazası, vb. durum karşısında acil eylem planlarının olmayışı da bu işlerin güvenli olmadığını göstermektedir. İş tekniği yönünden sürekli eğik, kıvrık ve katlanmış vücut yapısıyla çalışılacak olması, dikim işlerinin iş yükü açısından zorlayıcı ve yıpratıcı olabileceğini işaret etmektedir. İşin titizlik gerektirmesi ve kadınların bu tür işlerde gerekli hassasiyeti göstermeleri, kadın iş gücünü tercih edilebilir kılmaktadır. İşe devamlılığın zorunlu olmaması, genellikle tanıdık kişilerle ve doğayı sevenler için açık havada çalışılıyor olması kadın işgücünün bu işi tercih etmesinde olumlu katkılar sağlamaktadır. Öte yandan temiz su, sıcak öğün, temizlik, tuvalet yoksunluğu ile işe uzun ulaşım süresi gibi nedenler kadınların bu işlerdeki katılımını sınırlandıran unsurlardır.

İSG açısından fidan dikiminde, kadın iş gücü lehine gerekli sağlıklı ve güvenli ortamların oluşmadığı ancak bundan kaynaklanacak risklerin kadın iş gücü tarafından katlanılabilir bulunduğu ve gelecekte de bu koşullarda dahi kadınların bu işlere katılım göstereceği sonucu ortaya çıkmıştır. Ancak bu işlerin insan onuruna ve konforuna yakışır duruma getirilebilmesi için aşağıdakiler önerilerde bulunulabilir. Buna göre, ağaçlandırma işlerinde;

- Mesleki Yeterlilik Kurumu'nun işaret ettiği standartlarda eğitimli ve sertifikalı işçiler tercih edilmeli, kadın iş gücünün katılımı ve profesyonelleşmesi sağlanmalıdır.

- İşveren tarafindan ağaçlandırma sahalarında portatif tuvalet, lavabo gibi hem kişisel hem iş hijyenine yönelik ve de gün içinde sıcaktan soğuktan koruyacak tesisler (çadır, tente, vb.) oluşturulmalı veya götürülmelidir.

- Günlük ve periyodik olarak çalışanların kullandıkları el aletleri hem verim hem de iş güvenliği açısından denetlenmeli veya işçilerin kendileri tarafından kontrol edilmesi sağlanmalıdır.

- Çalışanların kişisel koruyucu donanım (toz, toprak, taş parçası vb. malzemeden koruyan gözlük, sahaya uygun ayakkabı, mevsime uygun iş kıyafeti, sıcağa ve yağmura karşı şapka vb.) kullanmaları sağlanmalıdır Fidan dikim işlerinde asal koruyucu donanımlardan biri eldiven olup 
mekanik risklere karşı koruma sağlayan (EN 388:2016 standardında); aşınmaya, kesilmeye, delinmeye ve yırtılmaya dirençli eldivenler kullandırılmalıdır.

- Çalışanların kullandıkları aletler ve kıyafetler beden ölçülerine uygun, vücudu kavrayacak şekilde, nefes alabilen yapıda ve dayanıklı olmalıdır. Yağmur ihtimaline karşı basit yağmurlukların bulundurulması, arazi içinde işçilerin kolayca görülebilmesi için fosforlu güvenlik yeleklerinin giyilmesi sağlanmalıdır.

- Ağaçlandırma işleri için risk değerlendirmeleri yöresel ve bölgesel olarak yapılmalı/yaptırılmalı ve yaygınlaştırılmalıdır. Tehlike ve risklere karşı alınacak önlemlerin yerine getirilip getirilmediği denetlenmeli, işçiliğin sürekliliği bu işlere uygun durum ve davranışlar çerçevesinde sağlanmalıdır.

\section{Açıklama}

Bu makale, Prof. Dr. Mehmet EKER danışmanlığında, Isparta Uygulamalı Bilimler Üniversitesi Lisansüstü Eğitim Enstitüsü'nde Fatma Gamze KORKMAZ tarafindan hazırlanan Yüksek Lisans tezinden türetilmiştir. İlgililere teşekkür ederiz.

\section{Kaynaklar}

Acar, H.H., Eker, M., 2001a. The women forest workers during the nursery operations in Turkey. Seminar Proceedings Women in Forestry-Strategies to increase women's participation in the forestry sector in Europe \& North America, 2-6 April, Viseu, Portugal, pp. 277-286.

Acar, H.H., Eker, M., 2001b. Orman fidanlık depo iş̧̧ilerinde ergonomik açıdan antropometrik özelliklerin araştırılması. 8. Ulusal Ergonomi Kongresi. 25-26 Ekim, İzmir, s. 229-239.

Acar, H.H., Eroğlu H., 2001. Ormanc1lıkta odun üretimi ve fidanlık-ağaçlandırma işçilerindeki sağlık sorunları üzerine bir araştırma. 8. Ergonomi Kongresi. 25-26 Ekim, İzmir, s. 9-14.

Acar, H.H., Üçüncü, K., 2020. İş Sağlığı ve Güvenliği. Nobel Tıp Kitapevleri.433 s., İstanbul.

Akay, D., Dağdeviren, M., Kurt, M., 2003. Çalışma duruşlarının ergonomik analizi. Gazi Üniversitesi Mühendislik Mimarlık Fakültesi Dergisi, 18 (3): 73-84.

Albayrak, M., 2020. Çalışma Ortamında Risk Etmenleri. Açıöğretim Fakültesi Yayınları, Atatürk Üniversitesi, Erzurum.

Bozkurt, A., 2017. Ormancılık çalışmalarında iş sağlığı ve güvenliği uygulamaları: Karabük Orman İşletme Müdürlüğü örneği. Yüksek Lisans Tezi, Bartın Üniversitesi, Fen Bilimleri Enstitüsü, Bartın.

Can, G.F., Fığlalı, N., 2014. Çalışma duruşlarının analizinde kullanılan yöntemlere eleştirel bir bakış, VII. Uluslararası İş Sağlığı ve Güvenliği Konferansı, 5-7 Mayıs, İstanbul, s.504516.

Eker, M., Çoban, H. O., Eroğlu, H., 2008. Ormancilık işlerinde aktüel teknoloji düzeyi ve ergonomi k1lavuzlarının uygulanabilirliği. 14. Ergonomi Kongresi, 30 Ekim - 1 Kasım, Trabzon, s. 402-411.

Eker, M., Çoban, H.O., 2019. The relationship between forest operations and climate change. International Conference on Climate Change and Forestry, November 12-15, Antalya, pp. 260-268.

Eker, M., Kılıç, K.E., 2021. Odun Hammaddesi Üretim İşlerinde Risk Değerlendirmesi. 4120-YL1-14 No.lu Proje Sonuç Raporu, Süleyman Demirel Üniversitesi, Isparta.

Elbir, H., 2019. Ormanc1lıkta iş sağlığı ve güvenliği algısı: İstanbul Orman Bölge Müdürlüğü örneği. Yüksek Lisans Tezi, İstanbul Üniversitesi-Cerrahpaşa, Lisansüstü Eğitim Enstitüsü, İstanbul.
Enez, K., 2008. Ormancilıkta üretim işçiliğinde antropometrik verilerin ve çalışma duruşlarının kaza risk faktörleri olarak değerlendirilmesi. Doktora Tezi, Karadeniz Teknik Üniversitesi Fen Bilimleri Enstitüsü, Trabzon.

Enez, K., Nalbantoğlu, S.S., 2015. Forestry activities evaluation of the method in terms of REBA. Suleyman Demirel University Journal of Engineering Sciences and Design, 3(3):127-131.

Engür, M.O., 2019. Odun üretim işlerinde risk değerlendirme kontrol listesi. Çalışma ve Sosyal Güvenlik Bakanlığı. https://www.ailevecalisma.gov.tr/medias/3752/ Erişim: 02.11.2019.

Eroğlu, H., Demir, A.G., Kadim, N., 2010. Adapazar1-Hendek orman fidanlığında çalışan işçiler üzerinde yapılan bir araştırma. III. Ulusal Karadeniz Ormancılık Kongresi, 20-22 Mayıs, Artvin, s. 608-614.

Forworknet, 1999. Focus on: Women in forestry. Industrial Activities Branch, ILO.

Gökbayrak, Ş., 2005. Orman İşçilerinin Çalışma Koşullarından Kaynaklı Risk Faktörleri Üzerine Bir İnceleme. Ankara Üniversitesi, Siyasal Bilgiler Fakültesi, Çalışma Ortamı, 78.

Göl, İ., 2018. Orman fidanlığında çalışan mevsimlik işçilerin çalışma koşullarının ve sağlık durumları algılarının değerlendirilmesi. Çankırı Karatekin Üniversitesi Sosyal Bilimler Enstitüsü Dergisi, 9 (2):19-32.

HSGM, 2021. Yetişkin beden kütle indeksi, hesaplama motoru. Halk Sağlığı Genel Müdürlüğü, Sağlık Bakanlı̆̆ı. https://hsgm.saglik.gov.tr/tr/beslenmehareket-hesaplamalar Erişim:11.02.2021.

ILO, 2018. ILO: Dünyanın birçok köşesinde kadınlar hala, erkeklere göre işgücü piyasasına daha az katılıyor. ILO Türkiye https://www.ilo.org/ankara/news/WCMS_619892/lang-tr/index.htm Erişim: 20.12.2018.

ILO, 2021. Toplumsal cinsiyet eşitliği programı. programlar ve projeler, Türkiye Ofisi, Uluslararası Çalışma Örgütü. https://www.ilo.org/ankara/projects/gender-equality/lang-tr/index.htm, Erişim: 20.02.2021)

Kaptan, S., 1973. Bilimsel Araştırma Teknikleri: Tez Hazırlama Yollar1. Ayyıldız Matbaası.

Karwowski, W., Marras, W.S., 1999. The Occupational Ergonomics Handbook. CRC Press, Florida.

Kaya, Ö., Özok, A.F., 2018. Hazır giyim işletmelerinin ergonomik risk etmenleri yönünden değerlendirilmesi. Journal of Engineering Sciences and Design, 6:263 - 270.

Kee, D., 2021. Comparison of OWAS, RULA and REBA for assessing potential work-related musculoskeletal disorders. International Journal of Industrial Ergonomics, 83:103-140.

Koç, S., Testik, Ö.M., 2016. Mobilya sektöründe yaşanan kasiskelet sistemi risklerinin farklı değerlendirme metotları ile incelenmesi ve minimizasyonu, Endüstri Mühendisliği Dergisi, 27 (2): 2-27.

Korkmaz, S., Alkan H., 2015. Orman köylerinde kadının toplumsal yaşamdaki rolü Isparta Orman İşletme Şefliği örneği. Türkiye Ormanc1l1k Dergisi, 16:141-151.

Korkmaz, M, Baykal, G.D.Ö., 2018. Kadın orman mühendislerinde iş doyumunu etkileyen faktörler ile iş doyumu ve örgütsel bağlılık arasındaki ilişki. Türkiye Ormancılık Dergisi, 19(1):83-90.

Küçükarslan, A.B., 2017. Ormancılık sektöründe iş sağlığı ve güvenliği. Yüksek Lisans Tezi, Üsküdar Üniversitesi, Sağlık Bilimleri Enstitüsü, İstanbul.

MYK, 2021. Orman Ağaçlandırma ve Fidan Yetiştirme İşçisi Seviye 3, Ulusal Meslek Standard. Mesleki Yeterlilik Kurumu, Referans Kodu 15UMS0475-3, $29 \mathrm{~s}$.

OGM, 2021a. Ormancılık İstatistikleri. Resmi İstatistik. Orman Genel Müdürlügüu. https://www.ogm.gov.tr/tr/ormanlarimiz/ resmi-istatistikler, Erişim: 28.05.2021.

OGM, 2021b. Orman Genel Müdürlüğü 2020 Y1lı İdare Faaliyet Raporu. Strateji Geliştirme Dairesi Başkanlığı, Orman Genel Müdürlügü. https://www.ogm.gov.tr/tr/e-kutuphane-sitesi/ Faaliyet Raporu, Erişim: 10.04.2021. 
Poschen, P., 1993. Forestry a safe and healthy profession. Unasylva, 44:1.

Starline, 2021. EN Avrupa eldiven standartları rehberi. Starline Kişisel Koruyucu Donanımlar. www.starlinesafety.com, Erişim: 03.02.2020.

TÜİK, 2020a. İstatistiklerle kadın. Türkiye İstatistik Kurumu. https://data.tuik.gov.tr/Bulten/Index?p=Istatistiklerle-Kadin, Erişim: 05.06.2020.

TÜIK, 2020b.. İstatistiklerle aile. Türkiye İstatistik Kurumu.

https://data.tuik.gov.tr/Bulten/Index?p=Istatistiklerle-Aile, Erişim: 05.06 .2020

TÜİK, 2021. İstatistik veri portalı. Türkiye İstatistik Kurumu. https://data.tuik.gov.tr/ Erișim: 05.03.2021.

UNFPA, 2019. Unfinished Business: The Pursuit of Rights and Choices for All. State of World Population 2019. https://asiapacific.unfpa.org/sites/default/files/pub-pdf/, Erișim:30.09.2019.

Üçüncü, K., Acar, H.H., 2020. Ergonomi. Nobel Akademik Yayıncılık. 651 s., İstanbul.
Ünver-Okan, S., Kaya, A., 2015. Orman fidanlıklarında fidan repikaj işlerinde çalışma duruşlarının REBA yöntemi ile analizi. Süleyman Demirel Üniversitesi Mühendislik Bilimleri ve Tasarım Dergisi,3(3):157-163.

Ünver-Okan, S., Acar, H.H., 2017. Determination of work postures with different ergonomic risk assessment methods in forest nurseries. Fresenius Environmental Bulletin, 26(12):73627371.

Unver-Okan, S., Acar, H.H., Ergenç, I., 2017. Using of Fine Kinney risk assessment method in the wood production process. FORMEC 2017 50th International Symposium on Forestry Mechanization Innovating the Competitive Edge: From Research to Impact in the Forest Value Chain, Brasov, Romania, 25th-29th September, vol. 1, pp. 285.

Ünver-Okan S., Acar H.H., Gümüş S., Ergenç İ., 2019. Evaluation of the risks in wood harvesting activities by the preliminary hazard analysis (PHA). Journal of Advanced Technology Sciences, 8(2):66-73.

Yıldırım, M., 1989. Ormancılık İş Bilgisi. İstanbul Üniversitesi Orman Fakültesi Yayınları, İstanbul. 